\title{
Pharmacological Activation of mGlu4 Metabotropic Glutamate Receptors Inhibits the Growth of Medulloblastomas
}

\author{
Luisa Iacovelli, ${ }^{1 \star}$ Antonietta Arcella, ${ }^{3 *}$ Giuseppe Battaglia, ${ }^{3}$ Simonetta Pazzaglia, ${ }^{4}$ Eleonora Aronica, ${ }^{5}$ Paola Spinsanti, ${ }^{1}$ \\ Alessandra Caruso, ${ }^{1}$ Enrico De Smaele, ${ }^{2}$ Anna Saran, ${ }^{4}$ Alberto Gulino, ${ }^{2}$ Mara D'Onofrio, ${ }^{3}$ Felice Giangaspero, ${ }^{2,3}$ and \\ Ferdinando Nicoletti ${ }^{1,3}$ \\ Departments of ${ }^{1}$ Human Physiology and Pharmacology and ${ }^{2}$ Experimental Medicine and Pathology, University of Rome "La Sapienza," 00185 Rome, Italy, \\ ${ }^{3}$ Istituto Neurologico Mediterraneo Neuromed, 86077 Pozzilli, Italy, ${ }^{4}$ Biotechnology Unit, Ente per le Nuove Tecnologie, Centro Ricerche Casaccia, 00060 \\ Rome, Italy, and ${ }^{5}$ Department of Neuropathology, Academic Medical Center, University of Amsterdam, 1105 AZ Amsterdam, The Netherlands
}

\begin{abstract}
Moving from the evidence that activation of type 4 metabotropic glutamate (mGlu4) receptors inhibits proliferation and promotes differentiation of cerebellar granule cell neuroprogenitors, we examined the expression and function of mGlu4 receptors in medulloblastoma cells. mGlu4 receptors were expressed in 46 of 60 human medulloblastoma samples. Expression varied in relation to the histotype (nodular desmoplastic $>$ classic $\gg$ large-cell anaplastic) and was inversely related to tumor severity, spreading, and recurrence. mGlu4 receptors were also found in D283med, D341med, and DAOY medulloblastoma cell lines, where receptor activation with the selective enhancer PHCCC inhibited adenylyl cyclase and the phosphatidylinositol-3-kinase pathway without affecting the mitogen-activated protein kinase, Sonic Hedgehog, and Wnt pathways. Interestingly, mGlu4 receptor activation reduced DNA synthesis and cell proliferation in all three cell lines. This effect was abrogated by the phosphatidylinositol-3-kinase inhibitor LY294002 [2-(4-morpholinyl)-8phenyl-4H-1-benzopyran-4-one]. In in vivo experiments, repeated subcutaneous injections of $N$-phenyl-7-(hydroxyimino) cyclopropa[b]chromen-1a-carboxamide (PHCCC) reduced the growth of D283med and DAOY cell xenografts in nude mice. More remarkably, subcutaneous or intracranial injections of PHCCC during the first week of life prevented the development of medulloblastomas in mice lacking one Patched-1 allele and $\mathrm{x}$-irradiated $1 \mathrm{~d}$ after birth. These data suggest that mGlu 4 receptor enhancers are promising drugs for the treatment of medulloblastomas.
\end{abstract}

Key words: medulloblastoma; metabotropic glutamate receptors; PHCCC; PI-3-K pathway; cerebellum; proliferation

\section{Introduction}

Medulloblastoma, the most common malignant brain tumor in children, is treated with surgery, followed by radiation and/or chemotherapy. However, these treatments are only partially effective and cause severe adverse effects including an impairment of CNS development in young children (Packer et al., 1994; Chintagumpala et al., 2001; Eleison et al., 2001). Survival at 5 years is $<50 \%$ for "high-risk" patients (e.g., for patients $<3$ years of age with metastases at presentation or residual tumors after surgery) (Gilbertson, 2004). There is a critical need for new, nontoxic therapies for medulloblastomas. Medulloblastomas originate from progenitor cells in the external granular layer of the developing cerebellum (Kleihues et al., 2000; Gilbertson, 2004).

Received Feb. 15, 2006; revised July 5, 2006; accepted July 5, 2006.

This work was supported in part by Grant C26A051555 from the University of Rome "La Sapienza."

L.I. and A.A. contributed equally to this work.

Correspondence should be addressed to Dr. Ferdinando Nicoletti, Department of Human Physiology and Pharmacology, University of Rome "La Sapienza," Piazzale Aldo Moro 5, 00185 Rome, Italy. E-mail: ferdinandonicoletti@hotmail.com.

M. D'Onofrio's present address: European Brain Research Institute, Via del Fosso di Fiorano 65, 00143 Rome, Italy. D0I:10.1523/JNEUROSCI.2285-06.2006

Copyright $\odot 2006$ Society for Neuroscience $\quad 0270-6474 / 06 / 268388-10 \$ 15.00 / 0$
Membrane receptors and intracellular signaling pathways that support proliferation and survival of cerebellar granule cell neuroprogenitors also support medulloblastoma growth. Studies of molecular genetics have shown a dysregulation of the Sonic Hedgehog ( $\mathrm{SHH})$ pathway, the canonical Wnt pathway, or the ERB-B pathway in both familiar and sporadic medulloblastomas (Gilbertson, 2004). SHH binds to the 12-TM receptor, Patched (PTC), which constitutively inhibits the 7-TM protein, Smoothened (Smo). Activated Smo acts on a multiprotein complex releasing the transcription factor Glil for the activation of gene expression (Ruiz et al., 2002a,b). Inactivating mutations of PTC1 cause the basal-cell naevus syndrome (Gorlin's syndrome), which predisposes to medulloblastomas (Hahn et al., 1996), and are found in $\sim 10 \%$ of sporadic medulloblastomas. Activating mutations of Smo are found in $\sim 5 \%$ of sporadic medulloblastomas (Pietsch et al., 1997; Raffel et al., 1997; Vorechovsky et al., 1997; Wolter et al., 1997; Reifenberger et al., 1998; Taylor et al., 2002). The alkaloid cyclopamine and other Smo inhibitors inhibit proliferation of and promote apoptosis of medulloblastoma cells in vitro and inhibit medulloblastoma growth in vivo (Berman et al., 2002; Romer et al., 2004). In the canonical Wnt pathway, Wnt glycoproteins bind to two membrane coreceptors (the 
7-TM receptor, Frizzled, and type-5/6 low-density lipoprotein receptor-related proteins) inhibiting phosphorylation of $\beta$-catenin by glycogen synthase kinase- $3 \beta$. Unphosphorylated $\beta$-catenin is not degraded and translocates to the nucleus where it combines with TCF/LEF (T-cell factor/lymphocyte enhancer factor) family of transcription factors and activates gene expression (Kalderon, 2002). Activating mutations of $\beta$-catenin and mutations of other proteins of the Wnt pathway occur in $\sim 15 \%$ of sporadic medulloblastomas (Zurawel et al., 1998; Eberhart et al., 2000; Huang et al., 2000; Yokota et al., 2002; Baeza et al., 2003). The tyrosine kinase receptor $E R B-B 2$ is found in a high percentage of human medulloblastoma samples, and its overexpression is associated with a poor prognosis (Gilbertson et al., 1997, 2001). Activation of the mitogen-activated protein kinase (MAPK) and the phosphatidylinositol-3-kinase (PI-3-K) pathways mediates the oncogenic effects of $E R B-B 2$ receptors and other tyrosine kinase receptors (Wang et al., 2001) in medulloblastomas (Gilbertson, 2004). Erlotinib and other ERB-B2 inhibitors are under clinical development for the treatment of medulloblastomas (Hernan et al., 2003). The identification of G-protein-coupled receptors that control the growth of medulloblastomas will give the strongest impetus to the molecular-targeted treatments of these tumors. We focused on type 4 metabotropic glutamate (mGlu4) receptors, which are expressed by cerebellar granule cell neuroprogenitors (Canudas et al., 2004). The study of these receptors is facilitated by the advent of the drug $N$-phenyl-7-(hydroxyimino) cyclopropa[b]chromen-1a-carboxamide (PHCCC), which behaves as a subtype-selective mGlu4 receptor enhancer (Maj et al., 2003; Marino et al., 2003). We report that (1) mGlu4 receptors are found in human medulloblastoma samples and are expressed by three medulloblastoma cell lines, (2) activation of mGlu4 receptors reduces medulloblastoma cell proliferation by inhibiting the PI-3-K pathway, and (3) systemic injection of PHCCC dramatically inhibits tumor growth in in vivo models of medulloblastomas.

\section{Materials and Methods}

Materials. Monoclonal anti-phospho-extracellular signal-regulated kinase 1/2 (ERK1/2), polyclonal anti-phospho AKT, and polyclonal antiAKT antibodies were from Cell Signaling Technology (Beverly, MA), polyclonal anti-ERK1/2 antibodies were from Santa Cruz Biotechnology (Santa Cruz, CA), and polyclonal anti- $\mathrm{G}_{\alpha z}$ antibodies were from Calbiochem (Darmstadt, Germany). (士)-PHCCC, 3,5-dihydroxyphenylglycine (DHPG), L-2-amino-4-phosphonobutanoate, AMPA, NMDA, kainate, $(R, S)$ - $\alpha$-methylserine-O-phosphate (MSOP), 6-methyl-2(phenyl-ethynyl)-6-pyridine (MPEP), CPCCOEt (7-hydroxyiminocyclopropan[b]chromen-1a-carboxylic acid ethyl ester), LY341495 [(2S)-2-amino-2-[(1S,2S)-2-carboxycycloprop-1-yl]-3-(xanth-9-yl) propanoic acid], baclofen, and LY294002 [2-(4-morpholinyl)-8-phenyl-4 H-1benzopyran-4-one] were from Tocris Cookson (Bristol, UK); pertussis toxin (PTX), forskolin (FSK), and isobutylmethylxanthine (IBMX) were from Calbiochem; 1,4-diamino-2,3-dicyano-1,4-bis(2-aminophenylthio)butadiene (UO126) was from Promega (Milan, Italy); 8Br-cAMP and epidermal growth factor (EGF) were from Sigma-Aldrich (Milan, Italy); (-)-2-oxa-4aminobicyclo[3,1,0]hexane-4,6-dicarboxylic acid (LY379268) was kindly provided by Eli-Lilly Research Laboratories (Indianapolis, IN).

Human medulloblastoma samples. The 60 cases of medulloblastoma included in this study were obtained from the files of the Department of Neuropathology of the Academic Medical Center (University of Amsterdam). Patients (41 males and 19 females; mean age at surgery, 13.4 years; range, 1-48 years) underwent surgical resection for a tumor located in the cerebellum. Two neuropathologists reviewed all cases independently and confirmed the diagnosis of medulloblastoma according to the revised World Health Organization classification of tumors of the nervous system (Kleihues et al., 2000). Informed consent was obtained for the use of brain tissue and for access to medical records for research purposes.

Construction of the medulloblastoma tissue array and immunocytochemistry. A tissue microarray containing cores from 60 medulloblastomas was constructed using standard techniques. Four cores $(0.5 \mathrm{~mm}$ diameter) were taken from each tumor (formalin-fixed, paraffin-embedded tissue). The tissue array was reviewed by two neuropathologists to ensure that each core contained representative tumor. The tissue array was sectioned at $6 \mu \mathrm{m}$, mounted on organosilane-coated slides (Sigma, St. Louis, MO), and processed for hematoxylin-eosin, as well as for immunocytochemical reactions, as described previously (Aronica et al., 2003; Geurts et al., 2005). For the detection of mGlu receptors, we used polyclonal anti-mGlu1a (1:100; Chemicon, Temecula, CA), mGlu2/3 (1:100; Chemicon), mGlu4 (1:100; Upstate Biotechnology, Lake Placid, NY), and mGlu5 (1:100; Upstate Biotechnology) receptors. Sections incubated without the primary antibody, with preimmune sera, or with the antibody preincubated with the antigenic peptide were essentially blank. We rated the degree of mGlu4 receptor staining on a semiquantitative four-point scale in which immunoreactivity was defined as follows: 0 , not present; 1 , weak; 2 , moderate; 3 , strong. Immunoreactivity in $>50 \%$ of medulloblastoma cells was considered positive.

Cell cultures. D283med, D341med, and DAOY human medulloblastoma cell lines (American Type Culture Collection, Manassas, VA) were cultured in DMEM containing non-hydrolyzable glutamine (Ultraglutamine; Cambrex, Milan, Italy), 10\% fetal calf serum (FCS), and antibiotics ( $100 \mathrm{U} / \mathrm{ml}$ penicillin and $100 \mu \mathrm{g} / \mathrm{ml}$ streptomycin).

$\left[{ }^{3} \mathrm{H}\right]$ thymidine uptake. Cells were seeded in 96-well plates at a density of $3 \times 10^{4} /$ well for D283med and D341med cells and $8 \times 10^{3} /$ well for DAOY cells. After $24 \mathrm{~h}$, cells were serum starved for $16-18 \mathrm{~h}$ and challenged with drugs for $24 \mathrm{~h}$. $\left[{ }^{3} \mathrm{H}\right]$ Thymidine $(1 \mu \mathrm{Ci} /$ well; Amersham Biosciences, Little Chalfont, UK) was added for the last 16-18 h. When present, PTX (10 nM) was preincubated for $16-18 \mathrm{~h}$.

Growth curves. Cells were plated at a density of $4 \times 10^{4}$ cells $/ 35 \mathrm{~mm}$ dish. PHCCC ( $30 \mu \mathrm{M}$, dissolved at the initial concentration of $30 \mathrm{~mm}$ in DMSO) was added every other day starting $4 \mathrm{~h}$ after plating. Cells were collected and counted at 2, 4, 7, and $9 \mathrm{~d}$ after seeding using a Burker chamber.

Assessment of cell toxicity. Apoptotic death in D283med cells was assessed as described previously (Canudas et al., 2004). Cells were washed once with PBS, fixed in $2 \%$ paraformaldeyde, and stained with the fluorescent chromatin dye Hoechst $33258(0.4 \mu \mathrm{g} / \mathrm{ml})$. Apoptotic cells were counted in four random microscopic fields per dish.

cAMP assay. Cells were grown to confluence in 96-well plates and serum starved for 16-18 h. Incubations were performed in HBSS buffer, $\mathrm{pH} 7.4$, containing $0.3 \%$ bovine serum albumin and $0.5 \mathrm{~mm}$ IBMX. Drugs were added $10 \mathrm{~min}$ before the addition of FSK $(10 \mu \mathrm{M})$. After 20 $\mathrm{min}$, the reaction was stopped with ice-cold ethanol. Some cultures were preincubated overnight with 10 nM PTX. cAMP content was determined by RIA (RPA509; Amersham Biosciences ).

Assessment of glutamate levels. Extracellular glutamate levels were measured by HPLC after pre-column derivatization with $O$-phthalaldehyde and mercaptoethanol. The system used an autosampler 507 (Beckman Instruments, Fullerton, CA), the programmable solvent module 126 (Beckman Instruments), an analytical reverse-phase C-18 column at $30^{\circ} \mathrm{C}$ (Ultrasphere ODS, $3 \mu \mathrm{m}$ spherical, $80 \AA$ pore, $2 \times 150 \mathrm{~mm}$; Beckman Instruments), and an RF-551 spectrofluorimetric detector (Shimadzu, Kyoto, Japan). Excitation and emission wavelengths were set at 360 and $450 \mathrm{~nm}$, respectively. The mobile phase consisted of $50 \mathrm{~mm}$ sodium phosphate, $\mathrm{pH} 7.2$, containing $10 \%$ methanol (A) and $50 \mathrm{~mm}$ sodium phosphate containing $70 \%$ methanol (B), at a flow rate of 0.3 $\mathrm{ml} / \mathrm{min}$. Gradient elution consisted of $98 \% \mathrm{~A}$ and $2 \%$ B initially for 10 min, was then increased to $98 \%$ B over $1 \mathrm{~min}$, maintained for $12 \mathrm{~min}$ to elute other substances, and then returned to the initial conditions before running the next samples. From peak areas, culture medium concentrations of glutamate were computed by the use of an external standard.

Western blot analysis. Cells were grown in $60 \mathrm{~mm}$ dishes to $\sim 50 \%$ confluency and serum starved for 16-18 h. Serum-free DMEM was again replaced $20 \mathrm{~min}$ before drug addition. The reaction was stopped by washing twice with ice-cold PBS. Cells were lysed using a Triton X-100 lysis 
buffer (10 mm Tris HCl, pH 7.4, $150 \mathrm{~mm} \mathrm{NaCl}$, 1\% Triton X-100, 1 mm EDTA, 10\% glycerol, 1 mu phenylmethylsulphonyl fluoride, $10 \mu \mathrm{g} / \mathrm{ml}$ leupeptin, $10 \mu \mathrm{g} / \mathrm{ml}$ aprotinin, $1 \mathrm{~mm}$ sodium orthovanadate, $50 \mathrm{~mm}$ sodium fluoride, and 10 mм $\beta$-glycerophosphate) for $15 \mathrm{~min}$, and cell lysates were clarified by centrifugation $(10,000 \times g$ for $10 \mathrm{~min})$. Protein $(80-100 \mu \mathrm{g})$ was separated by SDS-PAGE, blotted onto nitrocellulose membranes, and probed with antiphospho-ERK1/2 (1:1000), anti-phospho AKT (1:500), anti-AKT (1:1000), anti-ERK1/2 (1:2000), anti-G $\mathrm{G}_{\alpha z}(1: 250)$, or anti-mGlu4 receptor $(1: 1000)$ antibodies.

Cell transfection and luciferase assays. For the assessment of the Wnt pathway, cells were seeded in 96-well plates at a density of $3 \times 10^{4}$ / well. Transient transfections were performed in serum-free medium using LipofectAMINE 2000 (Invitrogen, San Diego, CA). A total of 0.4 $\mu \mathrm{g}$ of cDNA was transfected into each well, including luciferase reporter plasmid (150 ng), Wnt7a (200 ng), Renilla luciferase cytomegalovirus-driven internal reporter (10 ng), and carrier plasmid DNA (pGEM4Z; 400 ng). The luciferase reporter plasmid is the p4TCF, comprising four copies of a TCFresponsive element upstream of a TATA element luciferase coding sequence transcriptional unit (Bettini et al., 2002). For the assessment of the SHH pathway, D283med cells
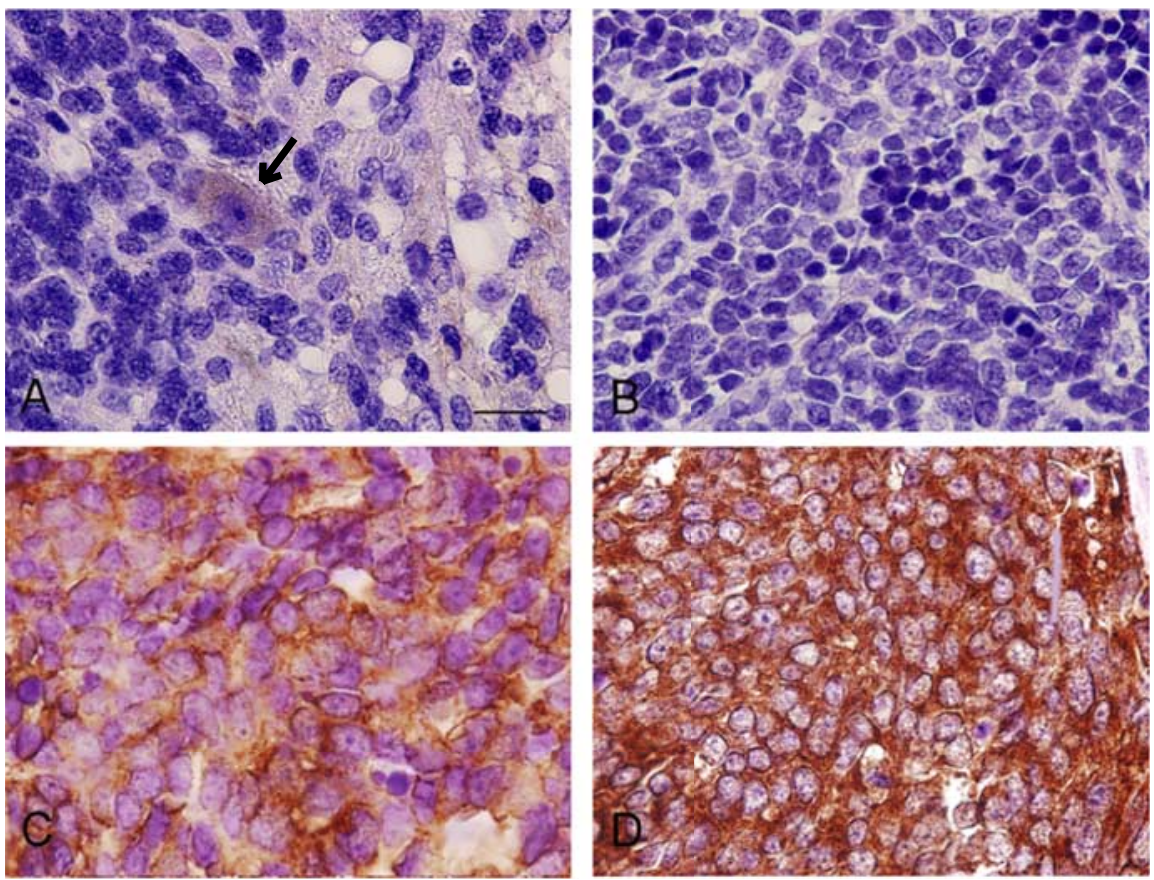

Figure 1. Expression of $\mathrm{mGlu1a}(\boldsymbol{A}), \mathrm{mGlu2} / 3(\boldsymbol{B}), \mathrm{mGlu} 4(\boldsymbol{C})$, and $\mathrm{mGlu} 5(\boldsymbol{D})$ receptors in medulloblastoma bioptic samples are shown. Sections are counterstained with hematoxylin- eosin. In $\boldsymbol{A}$, immunolabeling of a cerebellar Purkinje cell occasionally present in the field provides a positive internal control for mGlu1a receptor expression (arrow). Note that in $\mathbf{C}$, mGlu4 immunolabeling preferentially localizes to the cell membrane. Scale bar, $20 \mu \mathrm{m}$. were plated at a density of $25 \times 10^{4}$ cells/well in

24-well plates and transfected on the following day with a total amount of $0.5 \mu \mathrm{g}$ of DNA/well, including $0.2 \mu \mathrm{g}$ of $12 \times$ Gli-binding sequence luciferase reporter plasmid (GliRE) or control luciferase reporter devoid of the Gli binding sites (DeltaGLiRE) (Di Marcotullio et al., 2004) and 0.2 $\mu \mathrm{g}$ of the renilla-expressing vector pRL-TK (Promega), reaching the total DNA amount with empty pBluescript vector. Luciferase activity was assayed with a dual luciferase assay system (Promega), according to the manufacturer's instructions, in cell lysates collected 20-24 h after transfection.

Quantitative reverse transcription-PCR analysis. Reverse transcription (RT)-PCR analysis of mGlu4 receptors in medulloblastoma cell lines was performed as described previously (Iacovelli et al., 2002). Amplification of human mGlu4 receptor cDNA was performed using the following primers: forward, TGAGCTACGTGCTGCTGGCG; reverse, TCTCGGCTGACTGTGAGGTG. For $\beta$-actin amplification, we used the following primers, forward TGAACCCTAAGGCCAACCGTG and reverse GCTCATAGCTCTTCTCCAGGG, which span an intron and yield products of different sizes depending on whether CDNA or genomic DNA is used as a template (400 and $600 \mathrm{bp}$, respectively) (Iacovelli et al., 2002). Reaction conditions included an initial denaturation step $\left(94^{\circ} \mathrm{C} / 30 \mathrm{~s}\right)$, followed by $35-45$ cycles of $94^{\circ} \mathrm{C} / 30 \mathrm{~s} ; 60^{\circ} \mathrm{C} / 30 \mathrm{~s}$; and $72^{\circ} \mathrm{C} / 30 \mathrm{~s}$. A final extension step $\left(72^{\circ} \mathrm{C} / 10 \mathrm{~min}\right)$ concluded the reaction. Quantitative analysis of human Gli1 mRNA expression was performed on RNase-free DNase I (25 IU; Invitrogen)-treated RNA, reverse transcribed into cDNA (Superscript II reverse transcriptase; Invitrogen), by quantitative reverse transcription-PCR using the commercially available TaqMan assay reagents and the Applied Biosystems (Foster City, CA) PRISM 7700 sequence detection system. Standard curves were generated using six serial dilutions of a control cDNA mix. All amplification reactions were performed in triplicate, and the averages of the threshold cycles were used to interpolate standard curves and to calculate the transcript amount in samples using the SDS version 1.7a software (ABI). Results were expressed as arbitrary units, and mRNA expression was normalized with endogenous glyceraldehyde-3-phosphate dehydrogenase and $\beta$-actin transcripts, obtaining similar results.

Subcutaneous xenograft of D283med and DAOY cells in nude mice. Male $\mathrm{CD} 1$ nude mice were subcutaneously inoculated with $5 \times 10^{6}$ DAOY cells. After 1 week, mice were treated intraperitoneally daily for $7 \mathrm{~d}$ with $5 \mathrm{mg} / \mathrm{kg}$ PHCCC (dissolved in saline containing 20\% DMSO). Control animals received the vehicle alone. The size of the xenograft was measured in living animals at time 0 ( $12 \mathrm{~h}$ before the beginning of treatment), after 4 and $7 \mathrm{~d}$ of treatment, and at $7 \mathrm{~d}$ after the end of treatment using a device that allows an accurate bidimensional assessment of tumor size.

Tumorigenesis in Ptc ${ }^{+/-}$mice irradiated after birth. Mice lacking one Ptcl allele were generated by distruption of exons 6 and 7 in 129/SV ES cells. Ptc $\mathrm{co6}^{\text {neo/+ }}$ mice were genotyped using PCR primers, as described previously (Pazzaglia et al., 2002). Animals were housed under conventional conditions with food and water ad libitum and a $12 \mathrm{~h}$ light cycle. $\mathrm{X}$-ray irradiation was performed using a Gilardoni (Lecco, Italy) CHF G $\mathrm{x}$-ray generator operating at $250 \mathrm{kVp}, 15 \mathrm{~mA}$, with filters of $2.0 \mathrm{~mm} \mathrm{Al}$ and $0.5 \mathrm{~mm} \mathrm{Cu}(\mathrm{HVL}=1.6 \mathrm{~mm} \mathrm{Cu})$. One group of 14 mice was treated subcutaneously every day with PHCCC $(5 \mathrm{mg} / \mathrm{kg}$; dissolved in saline containing 50\% DMSO), and another group of 17 mice was given injections of PHCCC intracerebrally every other day $(10 \mathrm{nmol} / 0.5 \mu \mathrm{l} / 2 \mathrm{~min}$; dissolved in sterile saline containing 50\% DMSO injected through the scalp in the posterior region of the cerebellum, 1-2 $\mathrm{mm}$ posterior to lambda, under conditions of deep hypothermia). All treatments were performed during the first week of postnatal life starting $2 \mathrm{~h}$ before irradiation. Control groups received the vehicle alone.

\section{Results}

\section{Expression of $\mathrm{mGlu}$ receptors in human} medulloblastoma samples

We examined the expression of mGlu1a, mGlu2/3, mGlu4, and mGlu5 receptors by immunocytochemistry in bioptic human medulloblastoma samples from 60 patients [41 males and $19 \mathrm{fe}$ males; age, $13.4 \pm 1.5$ years (means \pm SEM) ]. Seven were "largecell anaplastic" medulloblastomas (6 from male and 1 from female patients; age, $12.7 \pm 4$ years), nine were "nodular desmoplastic" medulloblastomas (8 from male and 1 from female patients; age, $23.5 \pm 5.1$ years), and the remaining 44 samples were "classic" medulloblastomas (27 from male and 17 from female patients; age, $11.4 \pm 1.5$ years). Six patients, four of which 
A

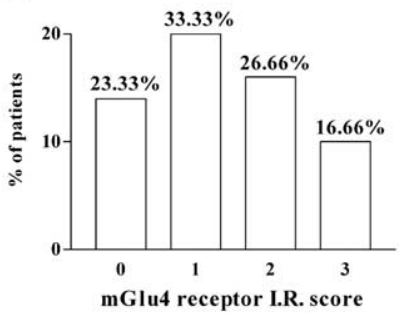

C Spinal cord metastases

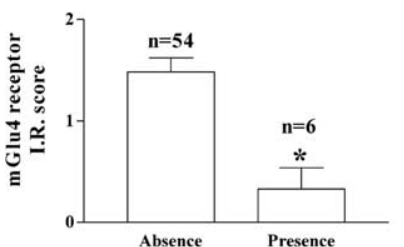

E

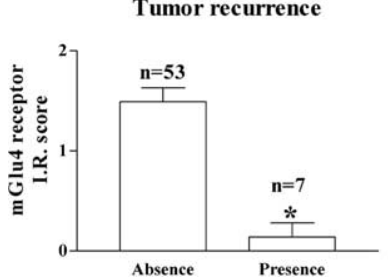

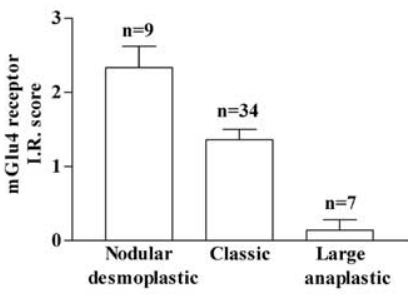

D
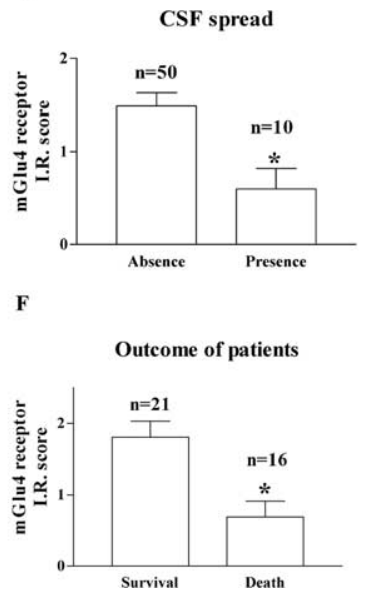

A

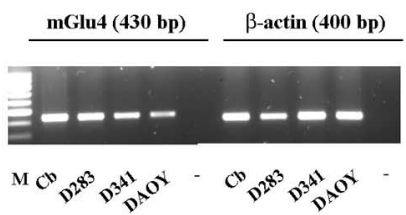

B

mGlu4

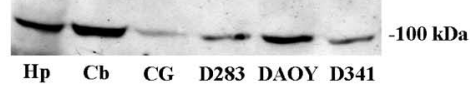

Figure 2. Expression of $m G l u 4$ receptors in human medulloblastomas in relation to the histological variant, tumor spreading, and clinical outcome. The extent of immunoreactivity (I.R.) was scored from 0 to 4 as outlined in Materials and Methods. $A$, The distribution of mGlu4 receptor expression in medulloblastoma samples from 60 patients. $\boldsymbol{B}$, Receptor expression in relation to the histological variant. $\boldsymbol{C}-\boldsymbol{E}$, The extent of expression in samples from patients with or without spinal cord metastases $(\boldsymbol{C})$, CSF spreading $(\boldsymbol{D})$, and tumor recurrence $(\boldsymbol{E})$. $\boldsymbol{F}$, The extent of expression in relation to the clinical outcome (survival or death). The outcome was unknown in 23 patients. Values are means + SEM. ${ }^{*} p<0.05$ (Student's $t$ test) versus the corresponding control group.

had large-cell anaplastic medulloblastomas, presented spinal cord metastases; in 9 patients, medulloblastoma cells were found in the CSF; the tumor recurred after surgery in 7 patients; 21 patients (none of whom had large-cell anaplastic medulloblastomas) survived at 5 years after surgery; 15 patients (including all patients with large-cell anaplastic medulloblastoma) died within 5 years after surgery. The clinical outcome of the remaining patients is unknown. None of the medulloblastoma samples showed any expression of mGlula (Fig. $1 A$ ) or mGlu2/3 (Fig. $1 B$ ) receptors. All medulloblastoma samples were strongly labeled with mGlu5 receptor antibodies (Fig. 1D). However, immunostaining did not correlate with the histological type, survival rate, presence of metastases, CSF spreading, and tumor recurrence (data not shown). Forty six of the 60 human medulloblastoma samples were immunopositive for $\mathrm{mGlu} 4$ receptors (immunopositive tumors were samples with $>50 \%$ of medulloblastoma cells immunoreactive for mGlu4 receptors). Immunoreactivity was mainly localized on the cell surface (Fig. 1C). Approximately $17 \%$ of medulloblastomas showed strong mGlu4 receptor immunoreactivity, $27 \%$ showed moderate immunoreactivity, and 33\% showed weak immunoreactivity (Fig. 2 A). Interestingly, mGlu4 receptor immunoreactivity highly correlated with the histological and clinical features of medulloblastomas. Expression levels showed the following rank order: nodular desmoplastic $>$ classic $\gg$ large-cell anaplastic medulloblastomas (Fig. $2 B$ ). Medulloblastomas from patients with spinal cord metastases, CSF spreading, and tumor recurrence showed significantly

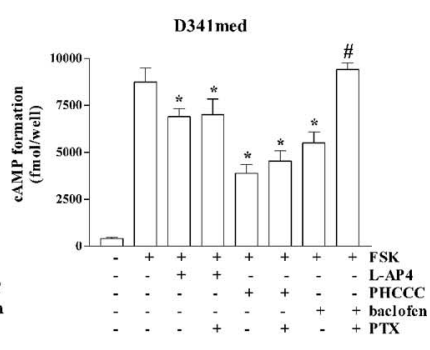

DAOY

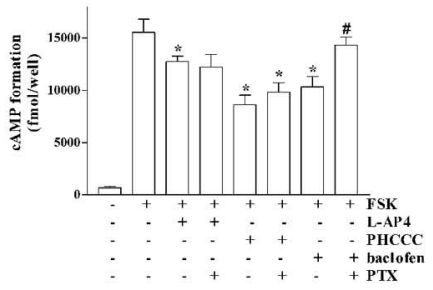

D

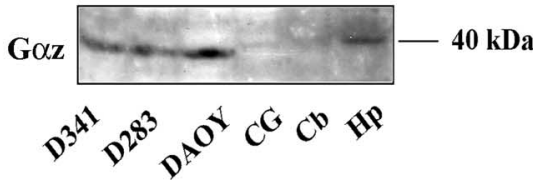

Figure 3. Medulloblastoma cell lines express functional mGlu4 receptors. $\boldsymbol{A}, \boldsymbol{B}$, Expression of mGlu4 receptor mRNA and protein in D283med, D341med, and DAOY cells. In $\boldsymbol{A}$, the lack of contamination by genomic DNA is shown by the single $\beta$-actin amplimer (see Materials and Methods). M, Markers. In $\boldsymbol{B}$, the monomeric $100 \mathrm{kDa}$ band of mGlu4 receptors is shown. $\boldsymbol{C}$, Inhibition of FSK (10 $\mu \mathrm{m})$-stimulated CAMP formation by L-AP-4 (100 $\mu \mathrm{m})$, PHCCC (30 $\mu \mathrm{m})$, or baclofen $(10 \mu \mathrm{m})$ in D283med, D341med, and DAOY cells preincubated or not with PTX (10 nM, applied $16-18 \mathrm{~h}$ before). Values are means \pm SEM of $6-12$ determinations. $p<0.05$ (oneway ANOVA and Fisher's PLSD) versus FSK alone $\left(^{*}\right)$ or versus FSK plus baclofen (\#). D, Immunoblot analysis of the $\mathrm{G} \alpha_{\mathrm{z}}$ protein in the three medulloblastoma cell lines. Note the absence of the protein in the rat cerebellum and in primary cultures of cerebellar granule cells. $\mathrm{Cb}$, Rat cerebellum; Hp, rat hippocampus; CG, extracts from primary cultures of rat cerebellar granule cells grown in medium containing $25 \mathrm{~mm} \mathrm{~K}^{+}$at $7 \mathrm{~d}$ in vitro.

lower expression levels of mGlu4 receptors (Fig. 2C-E); in addition, mGlu4 receptor expression was higher in patients who survived at 5 years after surgery (Fig. $2 F$ ). These data strongly suggest that a high expression of $\mathrm{mGlu} 4$ receptors in medulloblastomas is associated with a positive clinical outcome.

\section{Expression and signal transduction of mGlu4 receptors in medulloblastoma cell lines}

We searched for the expression of mGlu4 receptors in the D283med, D341med, and DAOY human medulloblastoma cell lines by combining RT-PCR and Western blot analysis. All three cell lines expressed both $\mathrm{mGlu} 4$ receptor $\mathrm{mRNA}$ and protein (Fig. $3 A, B)$. The band at $100 \mathrm{kDa}$ shown in the immunoblot of Figure $3 B$ corresponds to the deduced molecular size of the mGlu4 re- 


\section{D283med}
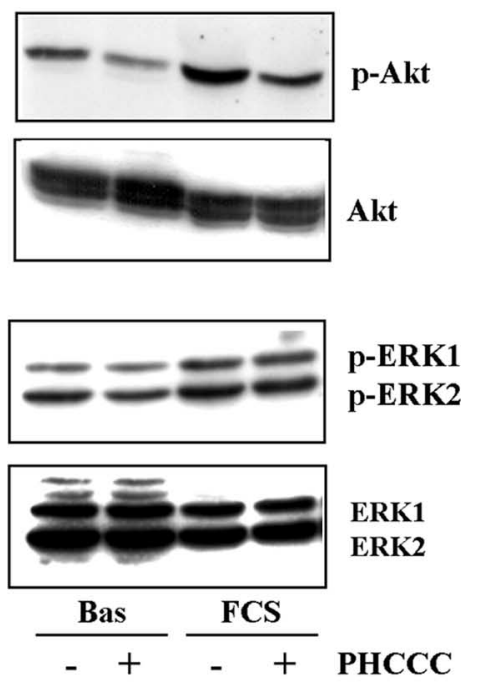

DAOY
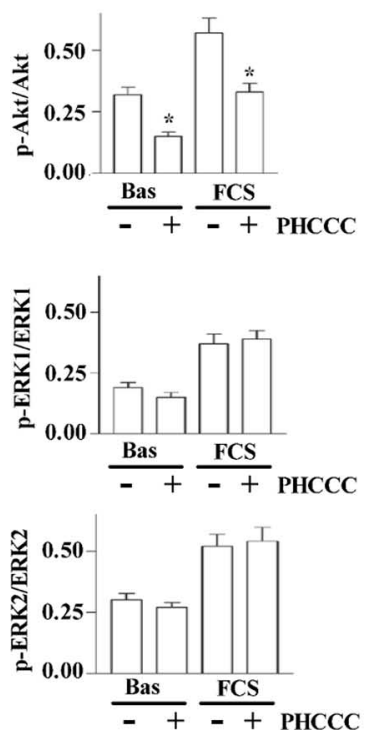
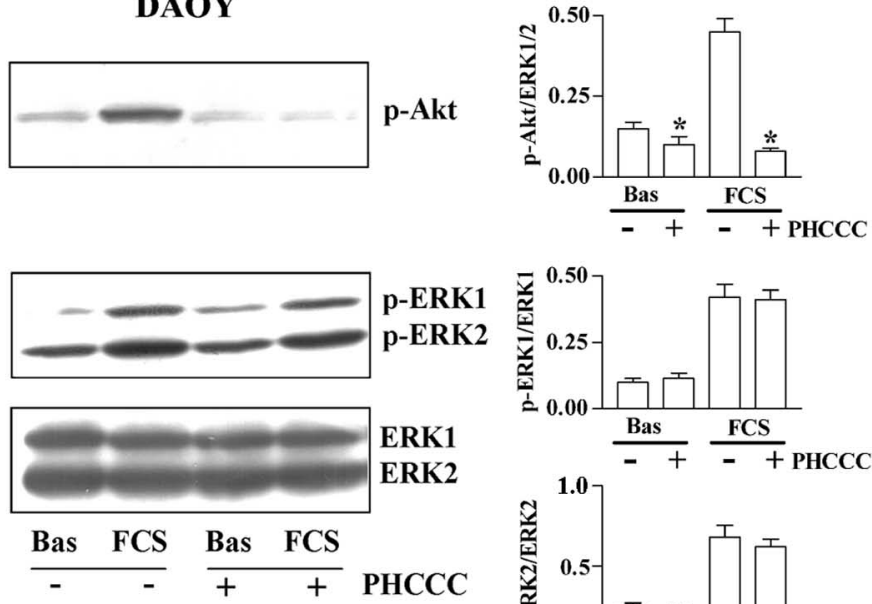

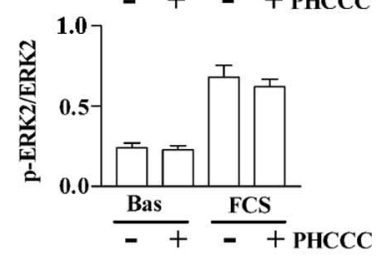

Figure 4. Inhibition of the PI-3-K pathway by PHCCC in medulloblastoma cells. D283med and DAOY cells were serum starved for $16-18 \mathrm{~h}$ and challenged with $10 \%$ FCS and/or PHCCC ( $30 \mu \mathrm{m}$ ) for $5 \mathrm{~min}$. For densitometric analysis, phosphorylated-AKT ( $\mathrm{p}$-Akt) values were normalized by the amount of nonphosphorylated AKT for D283med cells and for the average amount of nonphosphorylated ERK 1 and ERK2 for DAOY cells. Values are means \pm SEM of $6-12$ determinations. ${ }^{*} p<0.05$ (Student's $t$ test) versus the corresponding values obtained in the absence of PHCCC. Note that PHCCC has no effect on the stimulation of the MAPK pathway. The lanes are loaded with a different order for D283med and DA0Y cells. Bas, Basal.

ceptor monomer. High expression levels of mGlu4 receptors were found in the rat cerebellum and hippocampus used as positive controls (Fig. 3B).

To examine signal transduction in the three medulloblastoma cell lines, we used L-AP-4 as a nonsubtype-selective orthosteric agonist and PHCCC as a selective positive allosteric modulator (or enhancer) of mGlu4 receptors (Maj et al., 2003; Marino et al., 2003). By definition, PHCCC requires the presence of an agonist (either endogenous glutamate or a pharmacological agonist) to amplify receptor function. Because mGlu4 receptors are coupled to Gi proteins in heterologous expression systems (Tanabe et al., 1993; Iacovelli et al., 2004), we first examined the ability of L-AP-4 or PHCCC to inhibit FSK-stimulated cAMP formation. PHCCC (30 $\mu \mathrm{M})$ was more effective than L-AP-4 (100 $\mu \mathrm{M})$ or the $\mathrm{GABA}_{\mathrm{B}}$ receptor agonist baclofen $(10 \mu \mathrm{M}$, used as a positive control) in inhibiting CAMP formation in all three medulloblastoma cell lines (Fig. 3C). The different activity of $\mathrm{PH}$ CCC and L-AP-4 may reflect the influence of the endogenous glutamate released in the incubation buffer during the cAMP assay $(22 \pm 4.3,19 \pm 6.1$, and $30 \pm 2.9$ in D283med, D341med, and DAOY cells after 20 min of incubation in HBSS buffer, respectively; mean \pm SEM; $n=4-5$ ). Micromolar concentrations of ambient glutamate might have obliterated responses to L-AP-4 while allowing the amplifying effect of PHCCC. For this reason, we mainly used PHCCC in following experiments. Inhibition of cAMP formation mediated by $\mathrm{mGlu} 4$ receptors did not involve the classical coupling to Gi protein because it was insensitive to PTX (Fig. 3C). PTX instead blocked the cAMP response to baclofen (Fig. 3C). A possible G-protein candidate alternative to $\mathrm{Gi}$ was $\mathrm{Gz}$, a member of the Gi family, which is insensitive to PTX (Fields and Casey, 1997). Interest- ingly, the $\alpha$ subunit of $\mathrm{Gz}$ was found in all medulloblastoma cell lines, although it was not present in cultured cerebellar granule cells or in the adult cerebellum (Fig. 3D). We extended the study to additional signal transduction pathways that are relevant to the biology of medulloblastoma cells. Activation of mGlu4 receptors with PHCCC $(30 \mu \mathrm{M})$ reduced the PI-3-K pathway in D283med and DAOY cells incubated either in the absence or presence of $10 \%$ FCS (see immunoblots of phosphorylated AKT in Fig. 4). In contrast, PHCCC had no effect on the MAPK pathway in medulloblastoma cells (see immunoblots of phosphorylated ERK1/2 in Fig. 4). We examined the $\mathrm{SHH}$ pathway and the canonical Wnt pathway by measuring (1) constitutive Gli1 mRNA levels by real-time PCR in D283med and DAOY cells, (2) the expression of a reporter gene controlled by Gli1-responsive elements in D283med cells, and (3) the ability of Wnt7a, the Wnt isoform involved in the development of cerebellar granule cells (Lucas and Salinas, 1997), to stimulate the expression of a reporter gene controlled by Wnt-responsive elements in D283med cells. PHCCC had no effect on the SHH and the canonical Wnt pathways (Fig. 5A-C, respectively). 


\section{Activation of $\mathrm{mGlu} 4$ receptors reduces proliferation of medulloblastoma cells}

We examined the effect of mGlu4 receptor activation on DNA synthesis by measuring $\left[{ }^{3} \mathrm{H}\right]$ thymidine incorporation in D283med, D341med, and DAOY cells. In standard experiments, cells were incubated for $16-18 \mathrm{~h}$ in DMEM lacking FCS and exposed to drugs for an additional $24 \mathrm{~h}$ with $\left[{ }^{3} \mathrm{H}\right]$ thymidine added in the last 16-18 h. Extracellular glutamate concentrations assessed after $16-18 \mathrm{~h}$ of incubation in serum-free medium were $74 \pm 2.2,52 \pm 4.5$, and $44 \pm 11 \mu \mathrm{M}$ in cultured D283med, D341med, and DAOY cells, respectively (means \pm SEM; $n=3$ ). Activation of mGlu4 receptors with L-AP-4 or PHCCC reduced $\left[{ }^{3} \mathrm{H}\right]$ thymidine incorporation in all medulloblastoma cell lines (Fig. 6). At maximally effective concentrations (30 $\mu \mathrm{M})$, PHCCC inhibited DNA synthesis to a greater extent than L-AP-4 (100 $\mu \mathrm{M})$ (Fig. 6). Agonists of mGlu1/5 (DHPG, $100 \mu \mathrm{M}$ ), mGlu2/3 (LY379268, 0.1 $\mu \mathrm{M}$ ), AMPA/kainate (AMPA or kainate, both at $100 \mu \mathrm{M})$, NMDA $(100 \mu \mathrm{M})$, or $\mathrm{GABA}_{\mathrm{B}}$ (baclofen, $\left.10 \mu \mathrm{M}\right)$ receptors failed to reduce $\left[{ }^{3} \mathrm{H}\right]$ thymidine incorporation in any of the three medulloblastoma cell lines (Fig. 6). Kainate slightly enhanced $\left[{ }^{3} \mathrm{H}\right]$ thymidine incorporation only in D283med cells (Fig. 6). The antiproliferative action of PHCCC was also examined in cell growth experiments in which D283med, D341med, and DAOY cells were incubated in their growing medium containing 10\% FCS for $9 \mathrm{~d}$. PHCCC (30 $\mu \mathrm{M})$ applied every other day for $9 \mathrm{~d}$ significantly delayed cell growth in all cell lines (Fig. 7). This effect was not attributable to cell toxicity, because the number of apoptotic cells assessed by Hoechst chromatin staining was similar in cultures grown in the absence or presence of PHCCC (the percentage of cells with chromatin fragmentation or nuclear picknosis was $20 \pm 2.6$ and $15 \pm 2.1$ after treatment with vehicle and PHCCC, respectively; means \pm SEM; $n=5)$. Using the $\left[{ }^{3} \mathrm{H}\right]$ thymidine incorporation assay, we further characterized the action of PHCCC in D283med cells. In this cell line, inhibition of DNA synthesis by PHCCC could also be observed when $\left[{ }^{3} \mathrm{H}\right]$ thymidine incorporation was stimulated by either $10 \%$ FCS or $20 \mathrm{nM}$ EGF (Table 1). To shed light into the mechanism(s) responsible for the inhibition of DNA synthesis by PHCCC, the drug was combined with a battery of receptor antagonists or with drugs that interfere with intracellular transduction pathways. The action of PHCCC was essentially attenuated by the group III mGlu receptor antagonist MSOP $(200 \mu \mathrm{M})$ but not by the mGlul receptor antagonist CPCCOEt $(10 \mu \mathrm{M})$, the mGlu5 receptor antagonist MPEP $(1 \mu \mathrm{M})$, or the preferential $\mathrm{mGlu} 2 / 3$ receptor antagonist LY341495 $(0.1 \mu \mathrm{M})$. Among the selected inhibitors of intracellular signaling pathways, only the PI-3-K inhibitor LY294002 $(10 \mu \mathrm{M})$ prevented the action of PHCCC, whereas FSK $(10 \mu \mathrm{M})$, the cAMP analog 8Br-cAMP $(1 \mathrm{~mm})$, or PTX $(10 \mathrm{~nm}$, applied $12 \mathrm{~h}$ before PHCCC) were inactive. The MAPK inhibitor UO126 $(10 \mu \mathrm{M})$ reduced $\left[{ }^{3} \mathrm{H}\right]$ thymidine incorporation by itself but did not occlude the inhibitory action of PHCCC (Fig. 8). These data indicate that inhibition of D283med cell proliferation by PHCCC was mediated by the activation of mGlu4 receptors and involved the PI-3-K pathway. MSOP could also attenuate the antiproliferative action of PHCCC in D341med cells [ [ $\left.{ }^{3} \mathrm{H}\right]$ thymidine incorporation (in cpm/well): controls, $7300 \pm 550$; MSOP $(200 \mu \mathrm{M}), 7700 \pm 630$; PHCCC $(30 \mu \mathrm{M}), 2700 \pm 220$; PHCCC in the absence or presence of MSOP, $6250 \pm 700^{*}$; means \pm SEM of $12-36$ determinations; ${ }^{\star} p<0.01$ vs PHCCC alone, one-way ANOVA plus Fisher's PLSD].
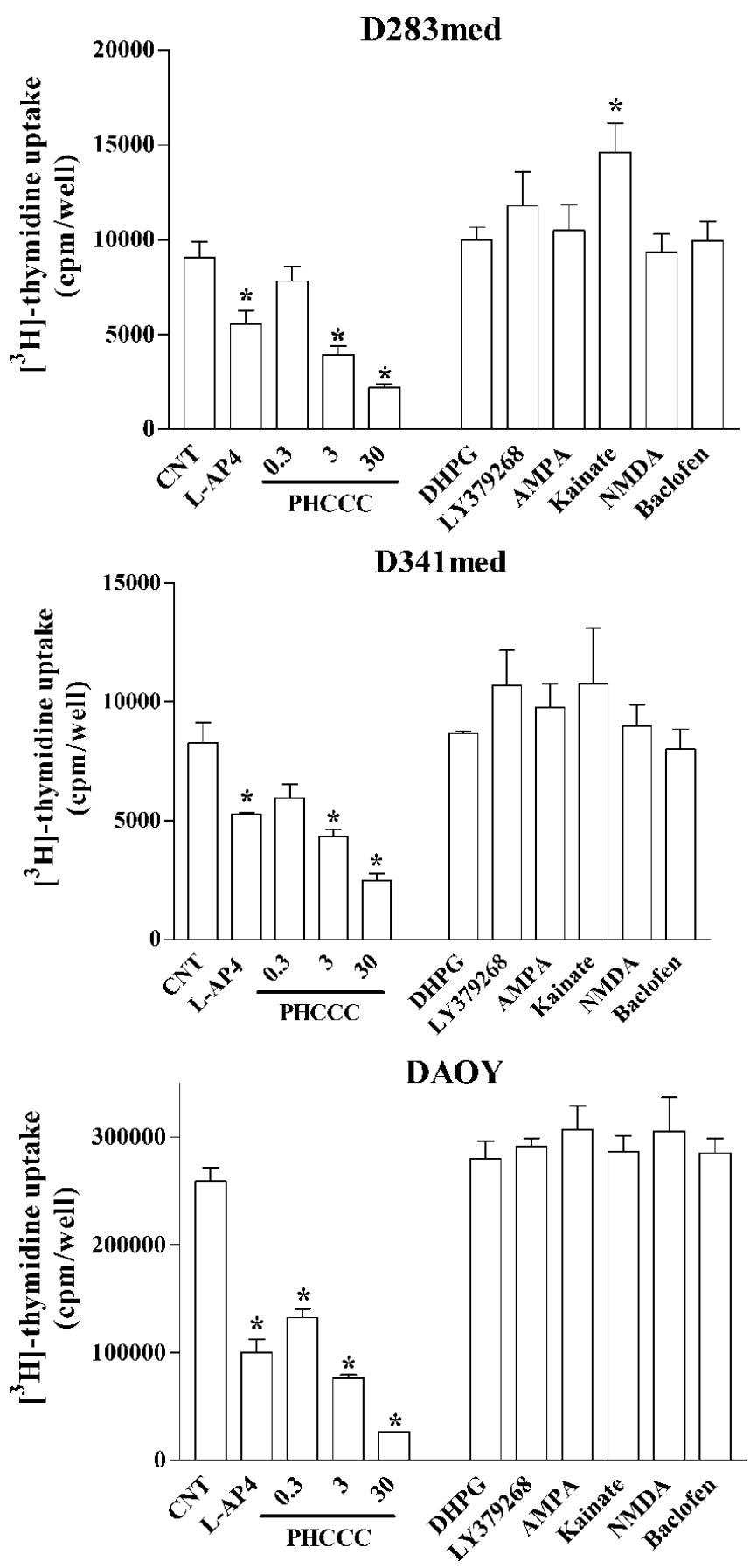

Figure 6. Activation of mGlu4 receptors inhibits DNA synthesis in medulloblastoma cells. $\left[{ }^{3} \mathrm{H}\right] \mathrm{Thymidine}$ incorporation was assessed in D283med, D341med, and DAOY cells serum starved for $16-18 \mathrm{~h}$ and challenged with L-AP-4 $(100 \mu \mathrm{M}), \operatorname{PHCCC}(0.3,3$, or $30 \mu \mathrm{M}), \operatorname{DHPG}(100$ $\mu \mathrm{M}), \operatorname{LY} 379268(0.1 \mu \mathrm{M})$, AMPA $(100 \mu \mathrm{M})$, kainate $(100 \mu \mathrm{M}), \mathrm{NMDA}(100 \mu \mathrm{M})$, and baclofen $(10 \mu \mathrm{M})$. Values are means \pm SEM of $6-60$ determinations. ${ }^{*} p<0.05$ (one-way ANOVA and Fisher's PLSD) versus controls (CNT).

\section{Activation of mGlu4 receptors with PHCCC inhibits medulloblastoma growth in mice}

To examine whether pharmacological activation of mGlu4 receptors could affect the growth of medulloblastomas in in vivo models, we implanted either DAOY or D283med cells under the skin of nude mice and monitored the growth of xenografts in living animals starting 1 week after implantation. In control mice, the area of the DAOY cell xenograft increased progressively up to $60-70 \%$ in the first $7 \mathrm{~d}$ and remained constant in the following 

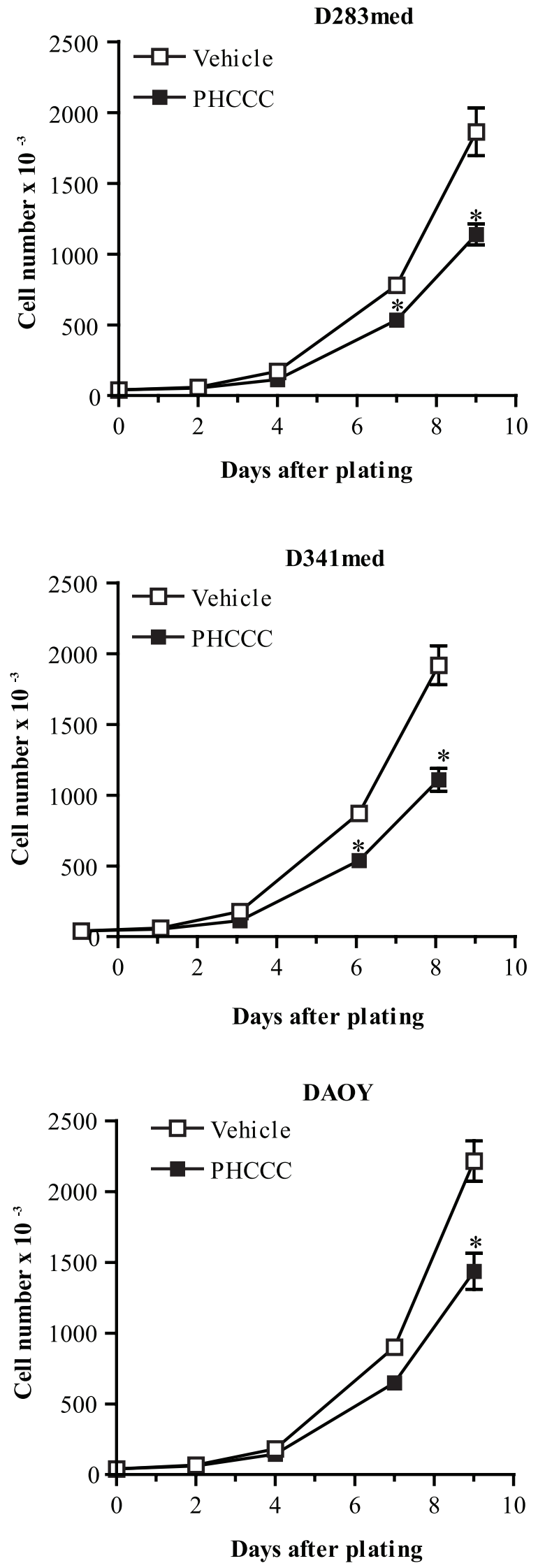

Figure 7. Continuous exposure to PHCCC reduces the growth of medulloblastoma cells. PHCCC (30 $\mu \mathrm{m})$ was applied to D283med, D341med, and DAOY cells every other day for $9 \mathrm{~d}$ starting $4 \mathrm{~h}$ after plating. Values are means \pm SEM of 12 determinations. ${ }^{*} p<0.05$ (Student's $t$ test) versus the respective controls (vehicle).
Table 1. PHCCC inhibits DNA synthesis in D283med incubated in the presence of serum or EGF

\begin{tabular}{lllc}
\hline & \multicolumn{4}{l}{$\left[{ }^{3} \mathrm{H}\right]$ thymidine incorporation $(\mathrm{cpm} /$ well) } \\
\cline { 2 - 4 } & None & FCS $(10 \%)$ & EGF $(10 \mathrm{~nm})$ \\
\hline Controls & $5600 \pm 970$ & $38,000 \pm 6600$ & $26,500 \pm 3200$ \\
PHCCC $(30 \mu \mathrm{M})$ & $2300 \pm 260^{*}$ & $21,000 \pm 3500^{*}$ & $19,000 \pm 700^{*}$ \\
\hline
\end{tabular}

Values are means \pm SEM of 12 determinations. ${ }^{*} p<0.05$ (Student's $t$ test) versus the respective controls.

$7 \mathrm{~d}$ (Fig. 9A). The area of D283med cell xenografts increased to a lower extent (up to $35-40 \%$ ) during the first $7 \mathrm{~d}$ and declined back to controls afterward (Fig. 9B). Repeated subcutaneous injections of PHCCC $(5 \mathrm{mg} / \mathrm{kg}$, injected daily for $7 \mathrm{~d}$ starting 1 week after cell implantation) inhibited the growth of both DAOY and D283med cell xenografts. Growth of DAOY cell xenografts did not recover at least $7 \mathrm{~d}$ after drug withdrawal (Fig. 9A). Remarkably, the D283med cell xenografts were no longer detectable at $7 \mathrm{~d}$ after PHCCC withdrawal (Fig. 9B). We then tested the activity of PHCCC in transgenic mice lacking one Ptc1 allele and $\mathrm{x}$-ray irradiated $1 \mathrm{~d}$ after birth, which develop medulloblastomas with an incidence of $>80 \%$ (Pazzaglia et al., 2002). Ptc ${ }^{\text {neo67/++ }}$ mice were generated through disruption of exons 6 and 7 in 129/SV ES cells and genotyped using PCR primers specific to the neo insert and wt regions, as described by Pazzaglia et al. (2002). Different groups of mice were treated with PHCCC or vehicle every other day during the first $8 \mathrm{~d}$ of life starting $2 \mathrm{~h}$ before $\mathrm{x}$-ray irradiation. The drug was either injected systemically $(5 \mathrm{mg} / \mathrm{kg}$, s.c.) or infused intracranially in the cerebellar region $(10 \mathrm{nmol} / 0.5 \mu \mathrm{l})$. We expect that subcutaneously injected PHCCC at doses of $5 \mathrm{mg} / \mathrm{kg}$ can penetrate the brain because it can reverse reserpine-induced bradykinesia in mice (Battaglia et al., 2006). Control Ptc ${ }^{\text {neo67/+ }}$ mice treated subcutaneously or intracranially with vehicle during the first $8 \mathrm{~d}$ of life showed the expected incidence of medulloblastomas (85-90\%) when autopsied after 10 weeks (Fig. 9C). Medulloblastomas appeared as large confluent tumor masses extending from the surface of the cerebellum and invading the underlining molecular and granular layers (Fig. 9D). At high magnification, tumors were characterized by small round cells with large hyperchromatic nuclei and small cytoplasm. The incidence of medulloblastomas was only 28 and $27 \%$ in mice treated systemically and intracranially with PHCCC, respectively (Fig. 9C). Of the four Ptc ${ }^{\text {neo67/+ }}$ mice treated systemically with PHCCC that developed medulloblastomas, two showed tumors of a much smaller size than in untreated mice (Fig. $9 C, E$ ); in one mouse, there was only a focal thickening of the external granules, which was considered as a pre-neoplastic lesion (Romer et al., 2004) (Fig. 9C,F). Tumor size was not smaller in the few mice treated intracranially with PHCCC that still developed medulloblastomas (Fig. 9C). This might reflect an unsuccessful drug injection within the time window of susceptibility in these unresponsive mice. Mice treated postnatally with PHCCC did not show signs of systemic toxicity, and their motor behavior was normal. Three mice treated intracranially with PHCCC showed the presence of ectopic granule cells in the molecular layer of the cerebellar cortex (Fig. 9G), suggesting an impaired migration of granule cell neuroprecursors. The cytoarchitecture of the cerebellar cortex was always normal in mice treated subcutaneously with PHCCC that did not develop medulloblastomas.

\section{Discussion}

The mGlu4 receptor is highly expressed by cerebellar granule cells (Kristensen et al., 1993; Tanabe et al., 1993; Santi et al., 1994; Makoff et al., 1996), where its main physiological role is the inhi- 


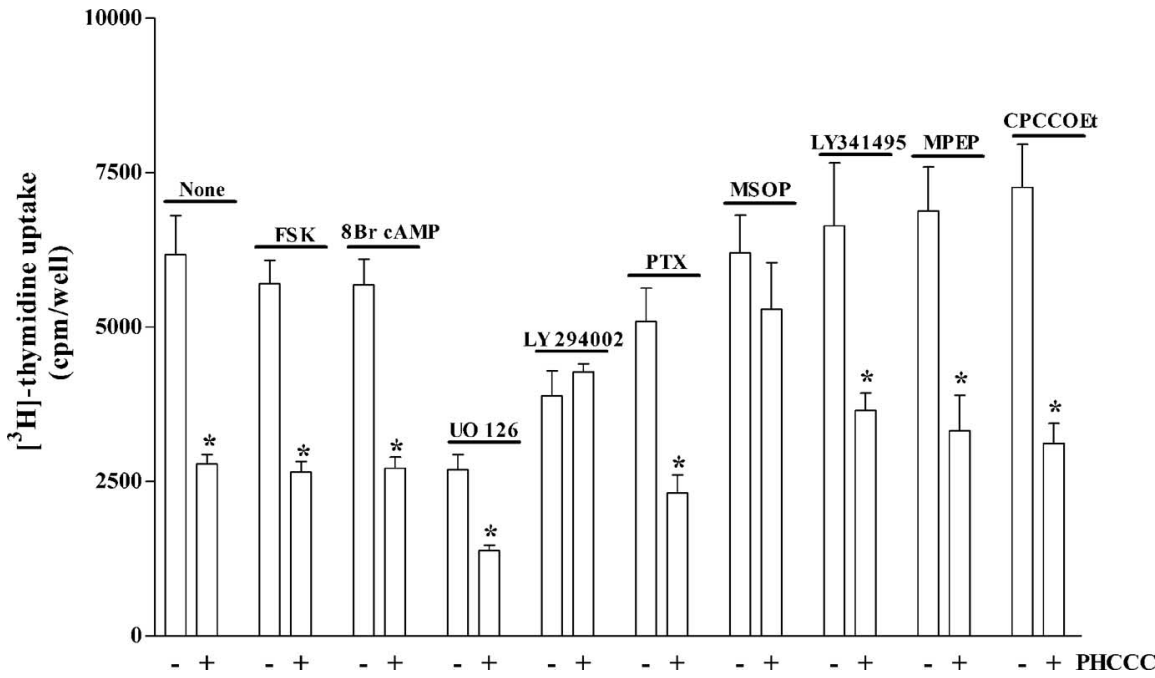

Figure 8. Inhibition of DNA synthesis by PHCCC $(30 \mu \mathrm{m})$ in D283med cells incubated in the absence or presence of mGlu receptor antagonists or drugs that interfere with intracellular signaling pathways. FSK, $10 \mu \mathrm{M} ; 8 \mathrm{Br}-\mathrm{CAMP}, 1 \mathrm{~mm}$; U0126, $10 \mu \mathrm{m} ; \mathrm{LY} 294002,10 \mu \mathrm{M}$; PTX, 10 nм (applied 16-18h before PHCCC); MSOP, $200 \mu \mathrm{m}$; LY341495, $0.1 \mu \mathrm{m}$; MPEP, $1 \mu \mathrm{m}$; CPCCOEt, $10 \mu \mathrm{m}$. Values are means \pm SEM of $6-24$ determinations. ${ }^{*} p<0.05$ (Student's $t$ test) versus the corresponding values obtained in the absence of PHCCC.
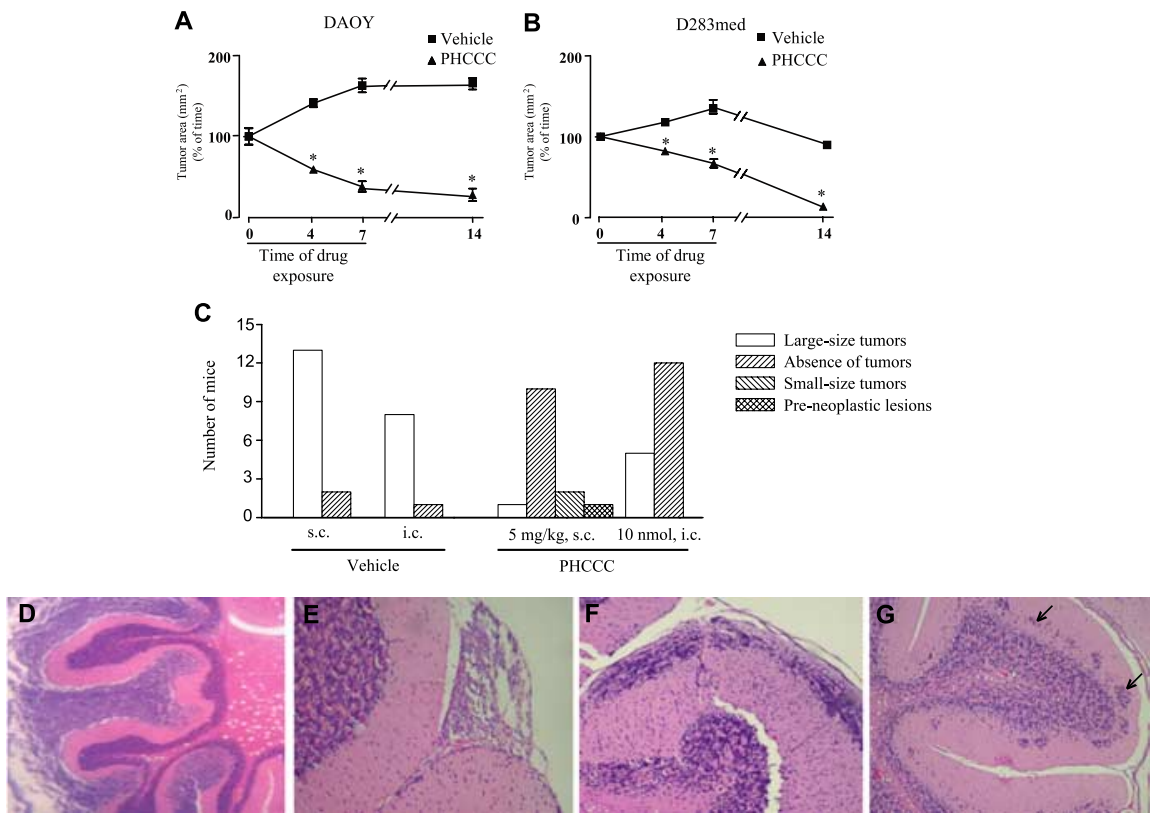

Figure 9. $\mathrm{PHCCC}$ inhibits the development of medulloblastomas in in vivo models. $A, B$, Systemic injections of PHCCC $(5 \mathrm{mg} / \mathrm{kg}$, S.C., once per day for $7 \mathrm{~d}$ ) reduces the growth of DAOY $(\boldsymbol{A})$ and D283med (B) cell xenografts implanted under the skin of nude mice. Tumor size was assessed on the day before the beginning of the treatment (time 0 , corresponding to $7 \mathrm{~d}$ after implantation), after 4 and $7 \mathrm{~d}$ of treatment, and $7 \mathrm{~d}$ after drug withdrawal (corresponding to day 14). Values are means \pm SEM of six to eight individual determinations. ${ }^{*} p<0.05$ (Student's $t$ test) versus the respective values obtained in mice treated with vehicle. $\mathbf{C}-\mathbf{G}$, Early postnatal treatment with PHCCC inhibits the growth of medulloblastoma in Ptc ${ }^{\text {neo67/+ }}$ mice irradiated after birth. $C$, The number of Ptc ${ }^{\text {ne067/+ }}$ mice x-ray irradiated at P1 and treated subcutaneously or intracerebrally with vehicle or PHCCC ( $5 \mathrm{mg} / \mathrm{kg}$, s.c., once per day for $7 \mathrm{~d}$; or $10 / \mathrm{nmol} / 0.5 \mu$ lintracranially every other day for $7 \mathrm{~d}$, during the first $7 \mathrm{~d}$ of life) expressing large-size tumors, small-size tumors, or pre-neoplastic lesions. D-G, Histological analysis of the cerebellum of Ptc ${ }^{\text {neo67/+ }}$ mice treated postnatally with vehicle or PHCCC and examined at 10 weeks of age. D, Large-sized tumor from a mouse treated systemically with vehicle (magnification, $100 \times$ ). $\boldsymbol{E}$, Small-sized tumor in one mouse treated systemically with PHCCC (magnification, $600 \times$ ). $\boldsymbol{F}$, Preneoplastic lesion in one mouse treated systemically with PHCCC (magnification, $400 \times$ ). G, Presence of ectopic granule cells in the molecular layer of the cerebellar cortex (arrows) in a mouse treated intracranially with PHCCC (magnification, 200X).

bition of glutamate release at parallel fiber-Purkinje cell synapses (Miniaci et al., 2001). However, in vitro studies disclosed functions of mGlu4 receptors that go beyond the regulation of synaptic transmission, including facilitation of neuronal survival
(Borodetz and D'Mello, 1998). We found that activation of mGlu4 receptor with PHCCC inhibits proliferation and promotes differentiation of cerebellar granule cell neuroprogenitors in culture (Canudas et al., 2004). This raised the attractive possibility that mGlu4 receptors could be expressed and functional in medulloblastoma cells. Here, we have shown that a large proportion of human medulloblastoma samples (41 of 60) and the D283med, D341med, and DAOY medulloblastoma cell lines express $\mathrm{mGlu} 4$ receptors. Expression in human medulloblastomas was inversely related to tumor severity in terms of histopathological features, invasivity, recurrence, and clinical outcome. The mGlu4 receptor might be viewed as a phenotypical marker of less malignant medulloblastomas (such as the nodular desmoplastic histotype) or might negatively regulate tumor growth. These two hypotheses are not mutually exclusive. In all three medulloblastoma cell lines, mGlu4 receptor activation primarily reduced cell proliferation. This was revealed by the use of PHCCC, which selectively amplifies mGlu4 receptor function independently of the concentrations of ambient glutamate (Maj et al., 2003; Marino et al., 2003). Remarkably, ligands of other mGlu receptor subtypes or agonists of ionotropic glutamate receptors had no effect on medulloblastoma cell proliferation, with the exception of kainate, which slightly increased $\left[{ }^{3} \mathrm{H}\right]$ thymidine incorporation.

mGlu4 receptors of medulloblastoma cells retained their classical negative coupling to adenylyl cyclase, although coupling was insensitive to PTX and perhaps involved $\mathrm{Gz}$ proteins. In addition, mGlu4 receptors negatively modulated the PI-3-K pathway without influencing the MAPK, $\mathrm{SHH}$, and Wnt pathways. This was unexpected because activation of mGlu4 receptors stimulates the PI-3-K pathway in cultured cerebellar granule cells (Iacovelli et al., 2002), which are the physiological counterparts of medulloblastoma cells. These observations offer a remarkable example of how receptor coupling to intracellular signaling pathways may vary in relation to the cell phenotype.

The PI-3-K pathway has an established role in tumor growth and is implicated in the development of medulloblastomas (Gilbertson, 2004; Pazzaglia et al., 2006). Activation of the PI-3-K pathway supports cell survival and also promotes cell proliferation via AKT-mediated phosphorylation of the cell-cycle inhibitor p21/WAF (Zhou, 2001). The lack of additive effects between PHCCC and the PI-3-K inhibitor LY294002 suggests that the antiproliferative action of mGlu4 re- 
ceptors in medulloblastoma cells involves the inhibition of the PI-3-K pathway.

PHCCC had a profound influence on medulloblastoma growth in vivo. Using mice subcutaneously implanted with D283med and DAOY cells, we could confirm in vivo that activation of mGlu4 receptors with PHCCC inhibits proliferation of medulloblastoma cells. Data obtained with irradiated Ptc neo67/+ mice indicate that pharmacological activation of mGlu4 receptors also affects early events in tumorigenesis. Hemizygous Ptc1 mice are particularly close to human pathology because (1) these mice have many features of the Gorlin syndrome, including predisposition to the development of medulloblastomas (Hahn et al., 1996; Oliver et al., 2005), and (2) a subset of hereditary and sporadic medulloblastomas show mutations in one copy of Ptc1 (Pietsch et al., 1997; Raffel et al., 1997; Vorechovsky et al., 1997; Wolter et al., 1997). Interestingly, tumorigenesis in these mice is much higher when they are irradiated at postnatal day 1 (P1) than at P10, and this window of susceptibility has been related to an increased PI-3-K activity in the cerebellum at P1 (Pazzaglia et al., 2006). There is a synergy between the SHH and PI-3-K pathways in Shh/Ptch-1-associated tumorigenesis (Rao et al., 2004), and the absence of insulin-like growth factor-II, which activates the PI-3-K pathway, suppresses the development of medulloblastomas in Ptch ${ }^{\text {neo67+ }} /$ Igf2 double knock-out mice (Hahn et al., 2000). It has been suggested that the high cerebellar PI-3-K activity at P1 supports the survival of granule cell neuroprogenitors carrying DNA damage in response to irradiation, thus facilitating tumorigenesis in Ptc ${ }^{\text {neo67+ }}$ mice (Pazzaglia et al., 2006). Inhibition of the PI-3-K pathway by PHCCC might critically interfere with this process, thereby limiting early tumorigenesis.

Together, our data suggest there might be valid alternative to cytotoxic drugs in the treatment of medulloblastomas, as already shown with inhibitors of the SHH pathway (Berman et al., 2002). A potential drawback of mGlu4 receptor enhancers might be related to their possible influence on cerebellar development (Canudas et al., 2004). However, it is noteworthy that none of our mutant mice treated with PHCCC early after birth showed gross abnormalities in motor behavior and only a minority of mice that received the drug in the cerebellar region showed the presence of ectopic granule cells in the molecular layer of the cerebellar cortex. Any potential effect on cerebellar morphology should be restricted to the critical period of cerebellar development, which usually precedes medulloblastoma growth. It will be interesting to establish the time window of tumor susceptibility to mGlu4 receptor activation and to examine whether mGlu4 receptor enhancers prevent tumor recurrence after surgery.

\section{References}

Aronica E, Gorter JA, Jansen GH, van Veelen CW, van Rijen PC, Ramkema M, Troost D (2003) Expression and cell distribution of group I and group II metabotropic glutamate receptor subtypes in Taylor-type focal cortical dysplasia. Epilepsia 44:785-795.

Baeza N, Masuoka J, Kleihues P, Ohgaki H (2003) AXIN1 mutations but not deletions in cerebellar medulloblastomas. Oncogene 22:632-636.

Battaglia G, Busceti CL, Molinaro G, Biagioni F, Traficante F, Nicoletti F, Bruno V (2006) Pharmacological activation of mGlu4 metabotropic glutamate receptors reduces nigro-striatal degeneration in mice treated with 1-methyl-4-phenyl-1,2,3,6-tetrahydropyridine. J Neurosci 26:72227229.

Berman DM, Karhadkar SS, Hallahan AR, Pritchard JI, Eberhart CG, Watkins DN, Chen JK, Cooper MK, Taipale J, Olson JM, Beachy PA (2002) Medulloblastoma growth inhibition by hedgehog pathway blockade. Science 297:1559-1561.

Bettini E, Magnani E, Terstappen GC (2002) Lithium induces gene expres- sion through lymphoid enhancer-binding factor/T-cell factor responsive element in rat PC12 cells. Neurosci Lett 317:50-52.

Borodetz K, D’Mello SR (1998) Decreased expression of the metabotropic glutamate receptor-4 gene is associated with the neuronal apoptosis. J Neurosci Res 53:531-541.

Canudas AM, Di Giorgi-Gerevini V, Iacovelli L, Nano G, D’Onofrio M, Arcella A, Giangaspero F, Busceti C, Ricci-Vitiani L, Battaglia G, Nicoletti F, Melchiorri D (2004) PHCCC, a specific enhancer of type 4 metabotropic glutamate receptors, reduces proliferation and promotes differentiation of cerebellar granule cell neuroprecursors. J Neurosci 24:10343-10352.

Chintagumpala M, Berg S, Blaney SM (2001) Treatment controversies in medulloblastoma. Curr Opin Oncol 13:154-159.

Di Marcotullio L, Ferretti E, De Smaele E, Argenti B, Mincione C, Zazzeroni F, Gallo R, Masuelli L, Napoletano M, Maroder M, Modesti A, Giangaspero F, Screpanti I, Alesse E, Gulino A (2004) REN(KCTD11) is a suppressor of Hedgehog signaling and is deleted in human medulloblastoma. Proc Natl Acad Sci USA 101:10833-10838.

Eberhart CG, Tihan T, Burger PC (2000) Nuclear localization and mutation of beta-catenin in medulloblastomas. J Neuropathol Exp Neurol 59:333-337.

Eleison DW, Clifford SC, Gajjar A, Gilbertson RJ (2001) What's new in neurooncology? Recent advances in medulloblastoma. Eur J Paediatr Neurol 7:53-66.

Fields TA, Casey PJ (1997) Signalling functions and biochemical properties of pertussis toxin-resistant G-proteins. Biochem J 321:561-571.

Geurts JJ, Wolswijk G, Bo L, Redeker S, Ramkema M, Troost D, Aronica E (2005) Expression patterns of group III metabotropic glutamate receptors mGluR4 and mGluR8 in multiple sclerosis lesions. J Neuroimmunol 158:182-190.

Gilbertson RJ (2004) Medulloblastoma: signalling a change in treatment. Lancet Oncol 5:209-218.

Gilbertson RJ, Perry RH, Kelly PJ, Pearson AD, Lunec J (1997) Prognostic significance of HER2 and HER4 coexpression in childhood medulloblastoma. Cancer Res 57:3272-3280.

Gilbertson RJ, Wickramasinghe C, Hernan R, Balaji V, Hunt D, JonesWallace D, Crolla J, Perry R, Lunec J, Pearson A, Ellison D (2001) Clinical and molecular stratification of disease risk in medulloblastoma. Br J Cancer 85:705-712.

Hahn H, Wicking C, Zaphiropoulous PG, Gailani MR, Shanley S, Chidambaram A, Vorechovsky I, Holmberg E, Unden AB, Gillies S, Negus K, Smyth I, Pressman C, Leffell DJ, Gerrard B, Goldstein AM, Dean M, Toftgard R, Chenevix-Trench G, Wainwright B, Bale AE (1996) Mutations of the human homolog of Drosophila patched in the nevoid basal cell carcinoma syndrome. Cell 85:841-851.

Hahn H, Wojnowski L, Specht K, Kappler R, Calzada-Wack J, Potter D, Zimmer A, Muller U, Samson E, Quintanilla-Martinez L, Zimmer A (2000) Patched target Igf2 is indispensable for the formation of medulloblastoma and rhabdomyosarcoma. J Biol Chem 275:28341-28344.

Hernan R, Fasheh R, Calabrese C, Frank AJ, Maclean KH, Allard D, Barraclough R, Gilbertson RJ (2003) ERBB2 up-regulates S100A4 and several other prometastatic genes in medulloblastoma. Cancer Res 63:140-148.

Huang H, Mahler-Araujo BM, Sankila A, Chimelli L, Yonekawa Y, Kleihues P, Ohgaki H (2000) APC mutations in sporadic medulloblastomas. Am J Pathol 156:433-437.

Iacovelli L, Bruno V, Salvatore L, Melchiorri D, Gradini R, Caricasole A, Barletta E, De Blasi A, Nicoletti F (2002) Native group-III metabotropic glutamate receptors are coupled to the mitogen-activated protein kinase/ phosphatidylinositol-3-kinase pathways. J Neurochem 82:216-223.

Iacovelli L, Capobianco L, Iula M, Di Giorgi Gerevini V, Picascia A, Blahos J, Melchiorri D, Nicoletti F, De Blasi A (2004) Regulation of mGlu4 metabotropic glutamate receptor signaling by type-2 G-protein coupled receptor kinase (GRK2). Mol Pharmacol 65:1103-1110.

Kalderon D (2002) Similarities between the Hedgehog and Wnt signaling pathways. Trends Cell Biol 12:523-531.

Kleihues P, Louis DN, Scheithauer BW, Rorke LB, Reifenberger G, Burger PC, Cavenee WK (2000) The WHO classification of tumors of the nervous system. J Neuropathol Exp Neurol 61:215-225.

Kristensen P, Suzdak PD, Thomsen C (1993) Expression pattern and pharmacology of the rat type IV metabotropic glutamate receptors. Neurosci Lett 155:159-162.

Lucas FR, Salinas PC (1997) WNT-7a induces axonal remodeling and increases synapsin I levels in cerebellar neurons. Dev Biol 192:31-44. 
Maj M, Bruno V, Dragic Z, Yamamoto R, Battaglia G, Inderbitzin W, Stoehr N, Stein T, Gasparini F, Vranesic I, Kuhn R, Nicoletti F, Flor PJ (2003) (-)-PHCCC, a positive allosteric modulator of mGluR4: characterization, mechanism of action, and neuroprotection. Neuropharmacology 45:895-906.

Makoff A, Lelchuk R, Oxer M, Harrington K, Emson P (1996) Molecular characterization and localization of human metabotropic glutamate receptor type 4. Brain Res Mol Brain Res 37:239-248.

Marino MJ, Williams Jr DL, O’Brien JA, Valenti O, McDonald TP, Clements MK, Wang R, DiLella AG, Hess JF, Kinney GG, Conn PJ (2003) Allosteric modulation of group III metabotropic glutamate receptor 4: a potential approach to Parkinson's disease treatment. Proc Natl Acad Sci USA 100:13668-13673.

Miniaci MC, Bonsi P, Tempia F, Strata P, Pisani A (2001) Presynaptic modulation by group III metabotropic glutamate receptors (mGluRs) of the excitatory postsynaptic potential mediated by mGluR1 in rat cerebellar Purkinje cells. Neurosci Lett 310:61-65.

Oliver TG, Read TA, Kessler JD, Mehmeti A, Wells JF, Huynh TT, Lin SM, Wechsler-Reya RJ (2005) Loss of patched and disruption of granule cell development in a pre-neoplastic stage of medulloblastoma. Development 132:2425-2439.

Packer RJ, Sutton LN, Elterman R, Lange B, Goldwein J, Nicholson HS, Mulne L, Boyett J, D’Angio G, Wechsler-Jentzsch K, Reaman G, Cohen BH, Bruce DA, Rorke LB, Molloy P, Ryan J, Lafond D, Evans AE, Schut L (1994) Outcome for children with medulloblastoma treated with radiation and cisplatin, CCNU, and vincristine chemotherapy. J Neurosurg 81:690-698.

Pazzaglia S, Mancuso M, Atkinson MJ, Tanori M, Rebessi S, Majo VD, Covelli V, Hahn H, Saran A (2002) High incidence of medulloblastoma following X-ray-irradiation of newborn Ptcl heterozygous mice. Oncogene 21:7580-7584.

Pazzaglia S, Tanori M, Mancuso M, Rebessi M, Leonardi S, Di Majo V, Covelli V, Atkinson MJ, Hahn H, Saran A (2006) Linking DNA damage to medulloblastoma tumorigenesis in patched heterozygous knockout mice Oncogene 25:1165-1173.

Pietsch T, Waha A, Koch A, Kraus J, Albrecht S, Tonn J, Sorensen N, Berthold F, Henk B, Schmandt N, Wolf HK, von Deimling A, Wainwright B, Chenevix-Trench G, Wiestler OD, Wicking C (1997) Medulloblastomas of the desmoplastic variant carry mutations of the human homologue of Drosophila patched. Cancer Res 57:2085-2088.

Raffel C, Jenkins RB, Frederick L, Hebrink D, Alderete B, Fults DW, James CD (1997) Sporadic medulloblastomas contain PTCH mutations. Cancer Res 57:842-845.

Rao G, Pedone CA, Valle LD, Reiss K, Holland EC, Fults DW (2004) Sonic hedgehog and insulin-like growth factor signaling synergize to induce medulloblastoma formation from nestin-expressing neural progenitors in mice. Oncogene 23:6156-6162.
Reifenberger J, Wolter M, Weber RG, Megahed M, Ruzicka T, Lichter P, Reifenberger G (1998) Missense mutations in SMOH in sporadic basal cell carcinomas of the skin and primitive neuroectodermal tumors of the central nervous system. Cancer Res 58:1798-1803.

Romer JT, Kimura H, Magdaleno S, Sasai K, Fuller C, Baines H, Connelly M, Stewart CF, Gould S, Rubin LL, Curran T (2004) Suppression of the Shh pathway using a small molecule inhibitor eliminates medulloblastoma in Ptc1(+/-)p53(-/-) mice. Cancer Cell 6:229-240.

Ruiz I, Palma V, Dahmane N (2002a) Hedgehog-Gli signalling and the growth of the brain. Nat Rev Neurosci 3:24-33.

Ruiz I, Ataba A, Sanchez P, Dahmane N (2002b) Gli and hedgehog in cancer: tumors, embryos and stem cells. Nat Rev Cancer 2:361-372.

Santi MR, Ikonomovic S, Wroblewski JT, Grayson DR (1994) Temporal and depolarization-induced changes in the absolute amounts of mRNAs encoding metabotropic glutamate receptors in cerebellar granule neurons in vitro. J Neurochem 63:1207-1217.

Tanabe Y, Nomura A, Masu M, Shigemoto R, Mizuno N, Nakanishi S (1993) Signal transduction, pharmacological properties, and expression patterns of two rat metabotropic glutamate receptors, mGluR3 and mGluR4. J Neurosci 13:1372-1378.

Taylor MD, Liu L, Raffel C, Hui CC, Mainprize TG, Zhang X, Agatep R, Chiappa S, Gao L, Lowrance A, Hao A, Goldstein AM, Stavrou T, Scherer SW, Dura WT, Wainwright B, Squire JA, Rutka JT, Hogg D (2002) Mutations in SUFU predispose to medulloblastoma. Nat Genet 31:306-310.

Vorechovsky I, Tingby O, Hartman M, Stromberg B, Nister M, Collins VP, Toftgard R (1997) Somatic mutations in the human homologue of Drosophila patched in primitive neuroectodermal tumours. Oncogene 15:361-366.

Wang JY, Del Valle L, Gordon J, Rubini M, Romano G, Croul S, Peruzzi F, Khalili K, Reiss K (2001) Activation of the IGF-IR system contributes to malignant growth of human and mouse medulloblastomas. Oncogene 20:3857-3868.

Wolter M, Reifenberger J, Sommer C, Ruzicka T, Reifenberger G (1997) Mutations in the human homologue of the Drosophila segment polarity gene patched (PTCH) in sporadic basal cell carcinomas of the skin and primitive neuroectodermal tumors of the central nervous system. Cancer Res 57:2581-2585.

Yokota N, Nishizawa S, Ohta S, Date H, Sugimura H, Namba H, Maekawa M (2002) Role of Wnt pathway in medulloblastoma oncogenesis. Int J Cancer 101:198-201.

Zhou BP (2001) Cytoplasmic localization of p21Cip1/WAF1 by Aktinduced phosphorylation in HER-2/neu-overexpressing cells. Nat Cell Biol 3:245-252.

Zurawel RH, Chiappa SA, Allen C, Raffel C (1998) Sporadic medulloblastomas contain oncogenic beta-catenin mutations. Cancer Res 58:896-899. 